\title{
The Impact of Applying the Accounting Disclosure in Accordance with the IFRS on Increasing Profitability in Listed Banks: An Analytical Study
}

\author{
Nabil Bashir Al-Halabi ${ }^{1}$ \\ ${ }^{1}$ Accounting Department, Faculty of Economics and Administration Sciences, Zarqa University, Jordan \\ Correspondence: Prof. Nabil Bashir Al-Halabi, Accounting Department, Zarqa University, P. O. Box 132222, \\ Zarqa 13110, Jordan. Tel: 962-797-390-188. E-mail: alhalabi.fcs@ gmail.com or nhalabi@zu.edu.jo
}

Received: September 8, 2017

Accepted: September 21, 2017

Online Published: October 1, 2017

doi:10.5539/ijef.v9n11p73

URL: https://doi.org/10.5539/ijef.v9n11p73

\begin{abstract}
The paper provided a content analysis on the impact of applying mandatory and voluntary disclosures (MD\&VD) in accordance with selected IAS and IFRS (independent variables) on increasing profitability measured by the net profit margin (the dependent variable) in banks listed at Damascus Stock Exchange (DSE). Data from a sample of 11 banks and their financial statements, including all notes, during period from 2010 till 2014 were gathered and processed using the statistical package of social sciences. The main results showed different significant impacts of applying mandatory and voluntary accounting disclosures under selected IFRS on increasing profitability in Syrian banks. However, when testing the separate application of each selected IAS and IFRS, results showed no such impacts, except for IAS18, on increasing profitability in Syrian banks. The main conclusion indicated that there is a need to develop IFRS internationally to lowering flexibility in selected IFRS aiming at increasing mandatory accounting disclosures, and some examples were provided for this purpose. The research also concluded that the Syrian SEC should harmonize with other governmental agencies to commit full application of all IAS and IFRS and, on the other hand, Syrian banks should be encouraged to disclose numerical and descriptive accounting disclosures in line with the IAS and IFRS within the Syrian context.
\end{abstract}

Keywords: mandatory and voluntary accounting disclosures, profitability, syrian banks

\section{Introduction}

The current decade has witnessed many attempts and concerns taking place after recent international financial crises regarding transparency and disclosure in financial statements of corporations (Bailey et al., 2004, p. 2491; Healy \& Pileup, 2003, p. 7; Bushman et al., 2004, p. 209). In fact, the interest in transparency and disclosure has not come from a vacuum, many external entities, shareholders and investors rely heavily on information published by corporations (Choi \& Wong, 2007, p. 15; Graham et al., 2005, p. 6). However, users do not have the power to obtain the information they need directly from corporate management and there is no doubt that the lack of transparency and disclosure requirements make accounting information contained in the financial statements misleading, and this is reflected in the decision-making by the shareholder or investor interested in this information (Nyabuti et al., 2016, p. 47; Hay et al., 2008, p. 11).

Early studies explained three theories related to the management's conduct with regard to levels and degrees of disclosure: (i) the theory of efficient contracts, where all parties are characterized by economic rationality, each trying to reduce the costs of the agency through contracts to prevent the exploitation of one party to another, so there is a positive correlation between the size of the corporation and the degree of disclosure, thus, rising external debt ratio and increasing management control over the corporation's affairs (Balkaoui, 2005, p. 120); (ii) the theory of opportunistic behavior, with the assumption that the choice of accounting methods and the type of disclosure is influenced by the opportunistic behavior of managers, that is, they are trying to maximize their wealth of ownership of the shares and the rewards they receive and thus choose accounting methods that would increase profitability (for example, getting higher management rewards and maximizing shareholders wealth) or decrease profitability (for example, avoiding political costs and increased taxes) at the expense of future periods (Chen \& Zhang, 2012, p. 602; Healy \& Palepu, 2003, p. 11); and (iii) the theory of information provision, where managers select accounting methods and the type of disclosure in a way that reflects the economic value of the 
corporation, so as to help investors to estimate the cash flows from their investments (Mensah et al., 2006, p. 51; Graham et al., 2005, p. 8) .

Recent development of characteristics of accounting information to be disclosed have been emerged from the IASB/FASB agreement in setting worldwide acceptance of the characteristics of accounting information, in term of: relevance (information is useful to the decision maker); reliability (information can be considered honest, complete and without calculation errors); verifiability (information can be reviewed and verified while ensuring the same results); comparability (information is comparable in different periods of time; understandability (there is reasonable knowledge in the nature of corporation business and its activities for reporting purposes); materiality (where negligence or omitting any item of financial statements can affect users of decision making processes); economic information (the application of cost-benefit concepts); and timely accounting information (Mackenzie et al., 2013; Iatridis \& Valahi, 2010, p. 11; Vojáčková, 2015, p. 179; Abu-Nasar \& Hmadat, 2016, p. 7; Mackenzie et al., 2013; Rapp, 2010, p. 12; Gherai \& Balaciv, 2011, p. 36).

Other studied pointed to main benefits of voluntary accounting disclosure (VAD) by providing different types of information relating to decision-makers, complementing mandatory disclosure, and fulfilling requirements of financing (Iatridis \& Valahi, 2010, p. 12; Vojáčková, 2015, p. 180; Bushman et al., 2004, p. 209). Despite the consensus on the need for disclosure as a vital requirement for transparency, this is confronted with many problems in practice, such as: (i) additional costs of issuing information; and (ii) more disclosure could lead other external parties and competitors get benefit from such disclosures (Nyabuti et al., 2016, p. 51; Shubita, 2015, p. 319; Hay et al., 2008, p. 19).

Based on the aforementioned views, this research explored the impact of applying accounting disclosures in accordance with the IFRS on increasing profitability in banks listed in Damascus stock exchange (DSE).

\section{Literature Review}

Disclosure of accounting information in published financial statements usually focused on identifying external and internal users of accounting information, objectives of using accounting information, the nature of accounting information that must be disclosed, types of accounting disclosure, and timing of disclosure of accounting information (Vojáčková, 2015, p. 177). In the context of mandatory disclosure, the corporation is obliged to disclose, where there is no option to accept or reject it, as the institutions are committed to the governance and professional requirements imposed by laws (Chen \& Zhang, 2012, p. 604). Mainly, accounting disclosures must be in accordance with International Accounting and International Financial Reporting Standards, thus, examples of disclosure under the IAS included : (i) presentation of financial statements (IAS1); accounting policies, changes in accounting estimates, and accounting errors (IAS8); property, plant, and equipment (IAS16); the revenue (IAS18); impairment of assets (36); and disclosure of financial instruments (IFRS7) (Nadia \& Rosa, 2014, p. 95; Abu-Nasar \& Hmadat, 2016, p. 724; Tanjitprom, 2013, p. 21; Mackenzie et al., 2013).

On the other hand, many studies pointed to benefits and objectives of voluntary accounting disclosures in preparing off-balance sheet reports related to human resources and the competitive environment; providing supplementary periodic financial and nonfinancial information emerged from the adoption of alternative accounting methods and policies in accordance with IAS and IFRS; assisting investors and creditors in assessing credit and liquidity risks about items of financial statements that are recognized and for other items that have not been recognized; and providing information on future financial events, future cash flows, and forecasting returns on investment in the corporation (Beaty \& Weber, 2003, p. 131; Kalyta, 2009, p. 1556; Mensah et al., 2006, p. 54; Han \& Wong, 1998, p. 108).

In respect of mandatory and voluntary accounting disclosures, the main disclosure items for banks as stated in the IAS1 are: (i) Information presented to the board of directors (disclosing changes in operations, future plans, and capital expenditure of the corporation); (ii) rules relating to the auditor's report (disclosing the extent of applying accounting methods based of IAS of local accounting standards, and the auditor's opinion); (iii) rules relating to presentation of financial statements (disclosing commitments, rights, and obligations of assets and liabilities contracts and their related cash flows); (iv) information to be presented in the profit or loss account or in notes (disclosing classification of expenses either by nature or by function); (v) changes in equity (disclosing results of continuing operations, other comprehensive income, treasury shares, options and reserves; (Abu-Nasar \& Hmadat, 2016, p. 23; Mackenzie et al., 2013).

Concerning mandatory and voluntary accounting disclosures, the main disclosure items for banks as stated in the IAS8 are: (i) changing accounting policies resulted in issuing a new accounting standard (disclosing the title of the standard or the interpretation and its effects on basic EPS, and the prospective or retrospective effects of changing accounting policies on profitability of corporations); (ii) prospective effects required on changes in 
accounting estimates (disclosing effects on profitability of corporations); and (iii) retrospective or prospective effects of accounting errors (disclosing effects on changing profits or losses of corporations) (Abu-Nasar \& Hmadat, 2016, p. 135; Mackenzie et al., 2013).

With regard to mandatory and voluntary accounting disclosures, the main disclosure items for banks as stated in the IAS16 are: (i) categories of property, plant and equipment (disclosing each group of the category, their capitalized values, and depreciation methods for depreciable assets); (ii) restriction of noncurrent assets (disclosing existence of assets restrictions and amounts of compensations for disposal or impairment of these assets); valuation of noncurrent assets (disclosing dates of valuation by independent valuators, the basis of revalued assets at either the cost model or the revaluation model, and amounts of revaluation surplus for the fair value model in the equity section) (Abu-Nasar \& Hmadat, 2016, p. 246; Mackenzie et al., 2013).

Concerning mandatory and voluntary accounting disclosures, the main disclosure items for banks as stated in the IAS18 are: (i) accounting policies used to recognize revenue; (ii) value of each main type of revenues; and (iii) separation of main revenues resulted from normal businesses of the corporation from abnormal revenues (Abu-Nasar \& Hmadat, 2016, p. 304; Mackenzie et al., 2013).

As for mandatory and voluntary accounting disclosures, the main disclosure items for banks as stated in the IAS36 are: (i) the mechanism and value of carrying amounts of noncurrent assets (disclosing the value of impairment loss, irrecoverable values, net fair values, values in use of noncurrent assets, impairment of cash generating units, and gains of reversing impaired assets and cash generating units (Avallone \& Quagli, 2015, p. 110).

In respect of mandatory and voluntary accounting disclosures, the main disclosure items for banks as stated in the IFRS7are: (i) focusing on the materiality element of financial instruments in the balance sheet and the statement of profit or loss (disclosing the carrying amounts and fair values of these instruments); (ii) focusing on three types of risks: credit, liquidity and market risks (describing guarantees of loans, analyzing maturity dates of obligations, sensitivity analysis in terms of gains and losses of categories of financial assets and liabilities and related numerical disclosures); and (iii) fair values hedging of financial instruments, cash flows hedging, and net foreign investment hedging (disclosing fair values of three types of hedging that have different measurement bases).

Other studies focused on components of voluntary accounting disclosure that include the following: general information of the corporation, such as historical information about the corporation and its organizational structure; the corporation's activity and future status, such as the statement of strategy and general objectives including marketing objectives and social goals; stock and shareholder information, such as the market value of equity, stocks, the market value of the corporation at the end of the year, and no. of total shareholders); management information, such as the age of directors, managers' degrees and experience, management responsibilities towards fulfilling environmental protection programs, and third party grants; results and ratios of financial and non-financial analyzes, such as dividends distribution policy geographical revenues classification according to clients; and information on governance: (disclosing the existence of a committee of governance in the corporation, details of names and qualifications of the members of the committee on governance, the functions of the committee on governance, and the no. of meetings of the committee on governance) (Iatridis \& Valahi, 2010, p. 17; Tanjitprom, 2013, p. 19; Ming \& Yazdanifard, 2014, p.159; Onali \& Ginesti, 2014, p. 633).

This research is in line with the aforementioned discussions aiming to explore the impact of applying mandatory and voluntary accounting disclosures in accordance with selected IFRS on increasing profitability in Syrian banks listed at Damascus stock exchange (DSE).

\section{Methodology of Research}

The research adopted a descriptive and analytical approach based on: research problem, hypotheses, method; and procedural definitions of the research variables.

\subsection{Research Problem}

The main research problem is to identify the impact of two types of accounting disclosure, mandatory and voluntary, in accordance with selected IFRS on increasing profitability in Syrian banks. Many corporations can be affected by the degrees and levels of accounting disclosure in financial statements and it is considered as an important tool in affecting financial performance of corporations and constituted a challenge to enhance the national economy. As a result, many external and internal users of financial statements in general, shareholders and investors in particular, have been misled by the lack of levels of accounting disclosure in published financial statements and reports, leading to instability in organizational activities of the whole economy. Thus, the 
following main questions are presented:

1- What is the impact of applying mandatory accounting disclosures, under selected IFRS, on increasing profitability in Syrian banks listed at Damascus stock exchange (DSE)?

1-1 What is the impact of applying mandatory accounting disclosures - IAS1, 8, 16, 18, 36, \& IFRS7- on increasing profitability in Syrian banks listed at DSE?

2- What is the impact of applying voluntary accounting disclosures, under selected IFRS, on increasing profitability in Syrian banks listed at Damascus stock exchange (DSE)?

2-1 What is the impact of applying voluntary accounting disclosures - IAS1, 8, 16, 18, 36, \& IFRS7- on increasing profitability in Syrian banks listed at DSE?

The research focused on exploring the impact of mandatory and voluntary accounting disclosure in accordance with the IAS and IFRS on increasing profitability of Syrian banks listed in Damascus stock exchange, as shown in Figure 1.

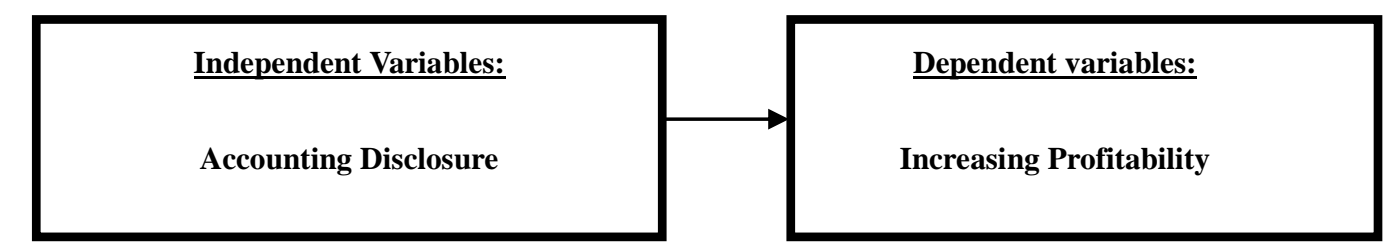

1- Mandatory Accounting Disclosures:

(IAS: 1, 8, 16, 18, 36; and IFRS: 7)

2- Voluntary Accounting Disclosures:

(IAS: 1, 8, 16, 18, 36; and IFRS: 7)

Figure 1. Research framework

Sources: selected IAS \& IAS: (Iatridis \& Valahi, 2010, p. 11; Vojáčková, 2015, p. 179; Abu-Nasar \& Hmadat, 2016, p. 7; Mackenzie et al., 2013).

\subsection{Research Hypotheses}

The research hypotheses are as follows:

1- HO1 there is no significant impact ( $\alpha \leq 0.05)$ of applying mandatory accounting disclosures- under selected IFRS- on increasing profitability in Syrian banks listed at Damascus stock exchange (DSE).

1-1 HO1-1 there is no significant impact ( $\alpha \leq 0.05)$ of applying mandatory accounting disclosures - IAS1, 8, 16, 18, 36, \& IFRS7- on increasing profitability in Syrian banks listed at Damascus stock exchange (DSE).

2- HO1 there is no significant impact $(\alpha \leq 0.05)$ of applying voluntary accounting disclosures- under selected IFRS- on increasing profitability in Syrian banks listed at Damascus stock exchange (DSE).

2-1 HO1-1 there is no significant impact $(\alpha \leq 0.05)$ of applying voluntary accounting disclosures - IAS1, 8, 16, $18,36, \&$ IFRS7- on increasing profitability in Syrian banks listed at Damascus stock exchange (DSE).

\subsection{Research Method}

The research method represented the research population (15) listed banks at Damascus stock exchange, based on the issued fiscal year of 2015, and sources of data gathering, from which a sample of 11 listed banks (that is, 11 financial statements that consisted of: income statements, financial position statements, ownership equity statements, cash flows statements, and all notes that are main parts of these statements) were processed and analyzed using a series period from 2010 till 2014. The research sample of 11 banks were selected based on the following criteria:

1)- The bank should be already listed in Damascus stock exchange during the current study; 
2)- The fiscal year for the bank should be ended at 31-12;

3)- The bank should not face abnormal events (such as consolidation) during the current study; and

4)- The bank should publish annual financial statements that are available regularly for this series of time (2010-2014).

Accordingly, the total number of banks that succeeded in fulfilling the aforementioned conditions is 11 (out of 15 banks) and considered as represented the sample of the study with the total cases of the content analysis is 55 (that is, $11 \times 5$ years, the series time period of this study). Thus, average figures of the financial statements of 11 banks for each year of the period were calculated to represent the data required for the application of the two types of accounting disclosure in accordance with selected IAS and IFRS to represent independent variables. Average figures of changes in net profit margins from continuing operations for the same series period were also perceived and calculated to represent dependent variables.

\subsection{Procedural Definitions}

Based on the framework of this research, the two types of mandatory and voluntary accounting disclosure and the selected IAS and IFRS; and the net profit margins of the sample studied are defined as follows:

1- Mandatory accounting disclosure: the corporation is obliged to disclose numerical and descriptive accounting disclosures as stated in IAS and IFRS, and follow rules, procedures and other SEC governmental professional requirements to achieve transparency of financial statements and assist users in making sound decisions.

2- Voluntary accounting disclosure: it is optional supplementary periodic financial and nonfinancial information, where the corporation is allowed by the IAS and IFRS (use of alternative accounting methods and accounting policies) or that resulted from its experience (disclosure reports on forecasting returns on investment and off-balance sheet disclosure reports for competition and risk avoidance purposes).

3- IAS1: stated mandatory and voluntary accounting disclosures related to presentation of financial statements of Syrian banks, included mainly into the profit or loss statement, the balance sheet, and the owners' equity of the Syrian listed banks in DSE.

4- IAS8: mandatory and voluntary accounting disclosures of changes in accounting policies, estimates and accounting errors of the Syrian listed banks in DSE

5- IAS16: stated mandatory and voluntary accounting disclosures related to two alternatives of noncurrent assets valuation of the sample studies.

6- IAS18: stated mandatory and voluntary accounting disclosures related to the revenue recognition in the sample studied.

7- IAS36: stated mandatory and voluntary accounting disclosures related to impairment of noncurrent assets for the sample studied.

8-IFRS7: stated mandatory and voluntary accounting disclosures related to disclosure of financial instruments in the sample studied.

9- Net profit margin: it represented the net profit and loss of the bank from normal businesses, and considered a reflection of profitability of the sample studied, thus positive or negative changes of net profits measured the percentage of profitability of selected banks during the series period 2010-2014.

\section{Results and Interpretations}

\subsection{Results of First Main Hypothesis HO-1}

In order to test the research hypotheses for the sample of 11 banks, the two types of accounting disclosure, on the number of observations 55 (11 banks $\times 5$ years), were applied with the following classification: the bank/s that disclosed the items of financial statements for the selected IAS and IFRS given number 1; and the bank/s that did not disclose given 0 . The aim is to separate those banks that were disclosing accounting information from those that were not. The results of these tests were as follows:

1 - HO1 there is no significant impact ( $\alpha \leq 0.05$ ) of applying mandatory accounting disclosures (MAD)- under selected IAS and IFRS- on increasing profitability in Syrian banks listed at Damascus stock exchange (DSE). The output of the regression test shown in Table 1 . 
Table 1.Results of the research hypothesis H01/ Net profit margin

\begin{tabular}{cccccccc}
\hline VIF & Tolerance & DF & Rsquare & $\beta$ & F & Sig. & Result ofTestingH01 \\
\hline 1.000 & 1.000 & 54 & 0.159 & 1.182 & 7.521 & 0.026 & Reject H01 \\
\hline
\end{tabular}

Results shown in Table 1 pointed to the significant $(\alpha<0.05)$ impact of applying the MAD, under selected IFRS, on increasing profitability of listed banks at Damascus stock exchange (DSE). According to the decision rule there is impact of applying mandatory accounting disclosures on increasing profitability of banks (sig. $=0.26$ ). This implied that the management of the sample studied were committing in general to the application IAS and IFRs, and requirements of the Syrian SEC and governance procedures. Further, not all Syrian banks commit equally to the MAD due to different specialized business criteria that showed different levels of importance of the disclosure items to be disclosed in financial statements of the sample studied. This implication is in line with Tanjitprom, 2013, p. 21.

\subsubsection{Results of Sub-main Hypothesis HO1-1}

There is no significant impact ( $\alpha \leq 0.05)$ of applying mandatory accounting disclosures - IAS1, 8, 16, 18, 36, \& IFRS7- on increasing profitability in Syrian banks listed at Damascus stock exchange (DSE).

Table 2 identified the results of this hypothesis for the research sample using the mandatory accounting disclosure (MAD) in Syrian banks.

Table 2.Results of the research hypothesis H01-1/ Net profit margin

\begin{tabular}{|c|c|c|c|c|c|c|c|c|}
\hline \multirow{2}{*}{$\mathrm{F}$} & \multirow{2}{*}{$\mathrm{R} 2$} & \multirow{2}{*}{$\mathrm{R}$} & \multicolumn{2}{|c|}{ CollinearityStatistics } & \multirow{2}{*}{ Sig. } & \multirow{2}{*}{$\mathrm{T}$} & \multirow{2}{*}{ Beta } & \multirow{2}{*}{ Elementsof MD } \\
\hline & & & VIF & Toler. & & & & \\
\hline \multirow{6}{*}{2.012} & \multirow{6}{*}{0.172} & \multirow{6}{*}{0.415} & 1.040 & 0961 & 0.368 & 0.907 & 0.110 & IAS1 \\
\hline & & & 1.026 & 0.975 & 0.444 & 0.770 & 0.093 & IAS8 \\
\hline & & & 1.034 & 0.967 & 0.046 & 1.947 & 0.237 & IAS 18 \\
\hline & & & 1.029 & 0.972 & 0.486 & 0.701 & 0.085 & IAS16 \\
\hline & & & 1.026 & 0.975 & 0.172 & 1.383 & 0.167 & IAS36 \\
\hline & & & 1.034 & 0.967 & 0.198 & 1.285 & 0.152 & IFRS7 \\
\hline
\end{tabular}

Results shown in Table 2 pointed to no impacts $(\alpha<0.05)$ of applying the VAD on, under selected IFRS, on increasing profitability of listed banks at Damascus stock exchange (DSE). According to the decision rule there is, in general, no impact for most of selected IAS and IFRS, on increasing profitability of Syrian banks. However, only IAS18 showed an impact (sig. $=0.046$ ) of applying mandatory accounting disclosure on increasing profitability in the sample studied, while the rest of selected IAS and IFRS showed no such impacts on increasing profitability. This implied that the management of the Syrian banks perceived less importance of mandatory accounting disclosure in the current environmental condition.

\subsection{Results of Second Main Hypothesis HO2}

There is no significant impact $(\alpha \leq 0.05)$ of applying voluntary accounting disclosures- under selected IAS and IFRS- on increasing profitability in Syrian banks listed at Damascus stock exchange (DSE). The output of the regression test shown in Table 3.

Table 3.Results of the research hypothesis H02/ Net profit margin

\begin{tabular}{cccccccc}
\hline VIF & Tolerance & DF & Rsquare & $\beta$ & F & Sig. & Result oftesting H02 \\
\hline 1.000 & 1.000 & 54 & 0.132 & 1.072 & 7.319 & 0.045 & Reject H02 \\
\hline
\end{tabular}

Results shown in Table 3 pointed to the significant $(\alpha<0.05)$ impact of applying the VAD on increasing profitability of listed banks at Damascus stock exchange (DSE). According to the decision rule there is impact of applying mandatory accounting disclosures on increasing profitability of banks (sig.= 0.045). This implied that the sample studied were competing each other and forcing their management to adopt techniques and approaches in presenting competitive and supplementary accounting disclosure in order to survive in the current local environment. This implication is in line with Iatridis and Valahi (2010). 


\subsubsection{Results of Sub-main Hypothesis HO1-2}

There is no significant impact $(\alpha \leq 0.05)$ of applying voluntary accounting disclosures - IAS1, 8, 16, 18, 36, \& IFRS7- on increasing profitability in Syrian banks listed at Damascus stock exchange (DSE). Table 4 identified the results of this hypothesis for the research sample using the voluntary accounting disclosure (VAD) in Syrian banks.

Table 4.Results of the research hypothesis H02-1/ Net profit margin

\begin{tabular}{|c|c|c|c|c|c|c|c|c|}
\hline \multirow{2}{*}{$\mathrm{F}$} & \multirow{2}{*}{$\mathrm{R} 2$} & \multirow{2}{*}{$\mathrm{R}$} & \multicolumn{2}{|c|}{ CollinearityStatistics } & \multirow{2}{*}{ Sig. } & \multirow{2}{*}{$\mathrm{T}$} & \multirow{2}{*}{ Beta } & \multirow{2}{*}{ Elementsof VD } \\
\hline & & & VIF & Toler. & & & & \\
\hline \multirow{6}{*}{2.032} & \multirow{6}{*}{0.152} & \multirow{6}{*}{0.415} & 1.040 & 0962 & 0.458 & 0.987 & 0.990 & IAS1 \\
\hline & & & 1.036 & 0.974 & 0.344 & 0.870 & 0.121 & IAS8 \\
\hline & & & 1.024 & 0.963 & 0.048 & 1.8347 & 0.216 & IAS 18 \\
\hline & & & 1.019 & 0.971 & 0.493 & 0.691 & 0.072 & IAS16 \\
\hline & & & 1.016 & 0.974 & 0.183 & 1.371 & 0.159 & IAS36 \\
\hline & & & 1.024 & 0.969 & 0.249 & 1.132 & 0.157 & IFRS7 \\
\hline
\end{tabular}

Results shown in Table 4 indicted that there is no significant $(\alpha \leq 0.05)$ impact of applying the VAD, under selected IFRS, on increasing profitability of listed banks at Damascus stock exchange (DSE). According to the decision rule there is no impact for most of selected IAS and IFRS on increasing profitability of Syrian banks. However, only IAS18 showed an impact (sig. = 0.048) of applying mandatory accounting disclosure on increasing profitability in the sample studied, while the rest of selected IAS and IFRS showed no such impacts on increasing profitability. This implied that the management of the Syrian banks perceived less importance of mandatory accounting disclosure in accordance with selected IAS and IFRS in the Syrian context.

\section{Conclusions and Recommendations}

\subsection{Conclusions}

Based on the research results and findings discussed in the aforementioned sections, the following are a number of conclusions that reflected the impact of the accounting disclosures in accordance with the IFRS on increasing profitability in listed banks at Damascus stock exchange (DSE):

1) Regarding mandatory accounting disclosure requirements as stated in selected IAS and IFRS, results showed significant impacts of applying all IFRS of the sample studied on increasing profitability in Syrian banks. However, when testing the separate application of each selected IAS and IFRS, results showed no such impacts, except for IAS18, on increasing profitability in Syrian banks. This implied that Syrian banks should be controlled and monitored by the SEC and other governmental agencies to commit full application of all IAS and IFRS in Syrian banks.

2) In respect of voluntary accounting disclosure as options allowed in selected IAS and IFRS, results showed significant impacts of applying all IFRS of the sample studied on increasing profitability in Syrian banks. However, when testing the separate application of each selected IAS and IFRS, results showed no such impacts, except for IAS18, on increasing profitability in Syrian banks. This implied that Syrian banks should be encouraged by the SEC and other governmental agencies to disclose numerical and descriptive accounting disclosures in line with the IAS and IFRS within the Syrian context.

3) There is a need to develop IFRS internationally to lowering flexibility in accounting standards aiming at increasing mandatory accounting disclosures where, results of this research showed significant impacts of the IAS18 whether the bank applied this standard in isolation or within other selected IAS and IFRS, for example, no differentiation in recording and classification of various types of revenues, earlier recording of revenues, and capitalization of some items of operating expenses (IAS18, and IFRS16).

4) The aforementioned findings put the light on the necessity of: (i) full application of updating (IFRS); (ii) imposing newly audit and governance procedures on elements of financial statements of Syrian listed banks.

\subsection{Recommendations}

The current study recommended the following:

1) There is a need for researchers to focus on selecting other IAS and IFRs .

2) It is beneficial for the Syrian government to adopt a regular revision of tax rules and procedures in order to 
guarantee full application of IAS and IFRS in other corporations.

3) More harmonization is needed between the SEC, the central bank, and other governmental agencies to reduce conflicting instructions and professional procedures in the Syrian context.

\section{Acknowledgments}

I gratefully acknowledge helpful assistance from participants of listed banks in Syria; and valuable comments from my colleagues in the accounting department at Zarqa University -Jordan.

\section{References}

Abu-Nasar, M., \& Hmadat, J. (2016). International Accounting and Financial Reporting Standards- Theoretical and Practical Issues (3rd ed.). DarWael Publication, No. 657.9.

Avallone, F., \& Quagli, A. (2015). Insight into the variables used to manage the goodwill impairment test under IAS 36. Advances in Accounting, 31(1), 107-114. https://doi.org/10.1016/j.adiac.2015.03.011

Bailey, W., Li, H., Connie, X., \& Zhang, R. (2004). Regulation fair Disclosure and Earnings Information: Market, Analyst, and corporate Responses. The Journal of Finance, 58(6), 2487-2541. https://doi.org/10.1046/j.1540-6261.2003.00613.x

Balkaoui, A. R. (2005). Accounting theory (5th ed.). Thomson learning, USA.

Beatty, A., \& Weber, J. (2003). The Effect of Debt Contracting on Voluntary Accounting Method Changes. The Accounting Review, 78(1), 119-142. https://doi.org/10.2308/accr.2003.78.1.119

Bushman, R. M., \& Smith, A. (2001). Financial Accounting Information and Corporate Governance. Journal of Accounting and Economics, 32, 237-333. https://doi.org/10.1016/S0165-4101(01)00027-1

Chen, J., \& Zhang, H. (2012). The Impact of Corporate Governance Code on Earnings Management: Evidence from Chinese Listed Companies. European Financial Management, 20(3), 596-632. https://doi.org/10.1111/j.1468-036X.2012.00648.x

Choi, J., \& Wong, T. (2007). Auditors Governance Function and Legal Environments: An International Investigation. Contemporary Accounting Research, 24(1), 13-46. https://doi.org/10.1506/X478-1075-4PW5-1501

Frank, B., \& Thomasm, H. (2004). On the Value of Transparency in Agencies with Renegotiation. Journal of Accounting Research, 42(5), 871-893. https://doi.org/10.1111/j.1475-679X.2004.00159.x

Gherai, D. S., \& Balaciv, D. E. (2011). From Creative Accounting and Enron Phenomenon to the Current Financial Crisis. Annals Understates Apulensis Series Oeconomica, 13(1), 34-41.

Graham, J. R., Harvey, C. R., \& Raigopal, S. (2005). The Economic Implications of Corporate Financial $\begin{array}{lllll}\text { Reporting. Journal of Accounting and } & \text { Economics, }\end{array}$ https://doi.org/10.1016/j.jacceco.2005.01.002

Han, J. Y., \& Wong, S. (1998). Political Costs and Earnings Management of Oil Companies During the 1990 Persian Gulf Crisis. The Accounting Review, 73(1), 103-117.

Hay, D., Robert, K., \& Ling, H. (2008). Evidence on the Impact of Internal Control and Corporate Governance on Audit Fees. International Journal of Auditing, 12(1), 9-42. https://doi.org/10.1111/j.1099-1123.2008.00367.x

Healy, P. M., \& Palepu, K. G. (2003). The Fall of Enron. Journal of Economics Perspectives, 17(2), 3-26. https://doi.org/10.1257/089533003765888403

Iatridis, G., \& Valahi, S. (2010). Voluntary IAS 1 accounting disclosures prior to official IAS adoption: An empirical investigation of UK firms. International Business and Finance, 24(1), 1-14. https://doi.org/10.1016/j.ribaf.2008.04.001

Kalyta, P. (2009). Accounting Discretion, Horizon Problem, and CEO Retirement Benefits. The Accounting Review, 84(5), 1553-1573. https://doi.org/10.2308/accr.2009.84.5.1553

Mackenzie, B., Coetsee, D., Njikizana, T., Selbst, E., Chamboko, R., Colyvasi, B., \& Hanekom, B. (2013). Interpretation and Application of International Financial Reporting Standards, John Wiley \& Son Inc.

Mensah, M., Nguyen, H., \& Prattipati, S. (2006). Transparency in Financial Statements: A Conceptual Framework from a User Perspective. Journal of American Academy of Business, 9(1), 47-61.

Ming, C., \& Yazdanifard, R. (2014). How Social Media Marketing can Influence the Profitability of an Online 
Company From a Consumer Point of View. Journal of Research in marketing, 2(2), 157-160. https://doi.org/10.17722/jorm.v2i2.55

Nadia, C., \& Rosa, V. (2014). The Impact of IFRS 9 and IFRS 7 on Liquidity in Banks: Theoretical Aspects. Procedia - Social and Behavioral Sciences, 164(31), 91-97. https://doi.org/10.1016/j.sbspro.2014.11.055

Nyabuti, V., Memba, F., \& Chege, C. (2016). Influence of Creative Accounting Practices on the Financial Performance of Companies Listed in the Nairobi Securities Exchange in Kenya. International Journal of Management and Commerce Innovation, 3(2), 45-59.

Onali, E., \& Ginesti, G. (2014). Pre-adoption Market Reaction to IFRS 9: A Cross-Country Event-Study. Journal of Accounting and Public Policy, 33(6), 628-637. https://doi.org/10.1016/j.jaccpubpol.2014.08.004

Rapp, M. S. (2010). Information Asymmetries and the Value-Relevance of Cash Flow and Accounting FiguresEmpirical Analysis and Implications for Managerial Accounting. Center for Entrepreneurial and Financial Studies (CEFS), TUM Business School- Technische Universitat Munchen, pp. 1-25. https://doi.org/10.2139/ssrn.1555652

Richardson, V. (2000). Information Asymmetry and Earnings Management: Some Evidence. Review of Quantitative Finance and Accounting, 15(4), 325-347. https://doi.org/10.1023/A:1012098407706

Shubita, M. F. (2015). The Impact of Income Smoothing on Earnings Quality in Emerging Markets: Evidence From GCC Markets. Journal of Emerging Economics, 5(3), 299-324. https://doi.org/10.1108/JAEE-04-2011-0011

Tanjitprom, N. (2013). The Role of Corporate Governance in Reducing the Negative Eggect of Earnings Management. International Journal of Economics and Finance, 5(3), 18-32.

Vojáčková, H. (2015). Financial Instruments: Meeting Disclosure Requirements Defined by IFRS 7 in Energy Industry in the Czech Republic. Procedia Economics and Finance, 25, 176-184. https://doi.org/10.1016/S2212-5671(15)00726-1

\section{Copyrights}

Copyright for this article is retained by the author(s), with first publication rights granted to the journal.

This is an open-access article distributed under the terms and conditions of the Creative Commons Attribution license (http://creativecommons.org/licenses/by/4.0/). 